\title{
The Spirit of Tolerance in Islam
}

Reza Shah-Kazemi

London and New York: I.B. Tauris, 2012. 165 pages.

This monograph challenges the notion that Islam is, at its core, an intolerant religion. Through a careful reading of the Qur' an, the Hadith literature, and extra-canonical texts, as well as examples from history, Reza Shah-Kazemi argues that Islam is rooted in an inclusivist ethic that permeates the founda- 
tions of Islamic belief and practice. He provides numerous examples of how Muslims have behaved in accordance with the Islamic values of unity (tawhīd), mercy (rahmān), and compassion (rahmah) elucidated in the Qur'an and the Hadith, and illustrated in history from the early Islamic period to recent centuries. This volume provides an academic and sophisticated reading of tolerance in Muslim history that is accessible to the scholar, student, and layperson interested in how Islam deals with religious minorities.

The introduction begins with the proposal that Islam is, at its foundation, committed to the principle of religious pluralism. Backed by eminent thinkers, including Wilfred Cantwell Smith (d. 2000) and John Locke (d. 1704), ShahKazemi describes this principle in terms of the "inalienable dignity" of all human beings as cited in Q. 30:30 and Q. 17:70: "We have bestowed dignity on the progeny of Adam [and Eve]" (p. 12). Examples of this principle are seen in the behavior of the Prophet as well as in that of his cousin and son-in-law Ali ibn Abi Talib, individuals who, in the author's perspective, communicated the rule of compassion (rahmah) throughout their lives. At the conclusion of this chapter, the author suggests that this practice be revived, for it accords with western secular principles that are not "an expression of its own specifically religious traditions," but rather a result of the intra-religious wars that accompanied the Reformation. Shah-Kazemi uses the rest of this volume to elucidate this spirit, which is best expressed in Q. 49:13: "O humanity, We have created you male and female, and We have made you into tribes and nations in order that you might come to know one another" (p. 19).

The remainder of the monograph is divided into two parts. Part 1, "A Glance at the Historical Record," surveys four major empires, examines their record of tolerance toward non-Muslim peoples, and concludes with a section on dhimmiss, those religious minorities protected under Islam based on the Ahl al-Kitab. Generally speaking, these communities were allowed to practice their faith because they were considered fellow monotheists who possessed religious texts. In retrospect, this section might have benefited from being placed at the beginning along with a discussion of how exclusivist Muslims, whom we might describe as "intolerant," explain away the Ahl alBayt's presence as a theological imperative situated in the Qur' an, historical reality, and a religious ethic that continues to be voiced among many Muslims today.

The first case study of tolerance focuses on the Ottomans (1299-1922). After a short explication of its millet system and the jizyah tax, Shah-Kazemi argues that this empire, which covered vast expanses of territory, should be viewed not only "as highly exceptional, but also as expressions of the spirit 
of tolerance central to the Islamic ethos" (p. 24). A combination of several factors, including the power dynamics of governance (which limited the sultan's power over the populace and involved the millets, guilds, futūwah (chivalry) orders, and waqf organizations, among others), the Ottomans' selfreferential attitude as "incorporators" rather than "colonisers," and the influence of Sufism (pp. 25-29), all resulted in the infusion of "a certain ethos into all levels of Ottoman society" (p. 32).

The Mughals (1526-1857) exhibited a fair degree of tolerance in respect to Hindus, due in large part to the combination of "mutual rapprochement, compromise, and synthesis that were at work in medieval Indian society at this time, trends that were reinforced on the Muslim side by Sufism, and on the Hindu side by Bhakti movements" (pp. 32-33). The fact that Hindus served in high governing positions under Akbar (r. 1556-1605) is one example of this ethic of cooperation. In fact, this ethos influenced every part of Mughal society, including the jurisprudential realm where the ulama (legal scholars) were " "commanded' by the sacred law of Islam to allow religious minorities the freedom to be governed by their own laws; and that law is itself but the surface expression of the tolerant spirit of Islamic revelation" (p. 38).

Shah-Kazemi's third case study is the Fatimids (909-1171), the Shi' ah empire that ruled over North Africa. When conquering Egypt in 969, the commander of the army issued a pledge of security (amān) on the caliph's behalf that included a protected status (dhimmah) for religious minorities. An important qualification of this particular extension was that it offered Sunnis, a majority now ruled by a Shi'ah minority, a degree of sectarian freedom not always present in such milieus. This degree of freedom was not one of radical agency; however, Sunnis, Christians, and other minorities were segregated more because of the era's political machinations than of anything situated in Islamic theology. As the author puts it: "One can rightly regard such practices as contingent and somewhat artificial creations of the jurists, which are in fact antithetical to the spirit defining the fundamental attitude to religious minorities in the Islamic revelation" (p. 45). An example of this accordance between Islamic values and law is found in al-Hakim's edict ( $\mathrm{si}$ jill) of tolerance issued in 1009, for which he referred to Q. 2:256: "There is no compulsion in religion."

The Jews of medieval Europe were often targeted by violence, with the exception of al-Andalus (Muslim Spain, 711-1492), a milieu that scholars portray as a "golden age" of Jewish culture. The experience of Jews - and of Christians, for that matter - within this Islamic empire could be described as including discrimination; however, persecution was rare. The tolerance evident 
there not only allowed a certain degree of freedom for non-Muslims, but also encouraged the flowering of a culture in which all of its inhabitants, be they Jews, Christians, or Muslims, participated: "Muslim tolerance allowed Jews and Christians, as well as Muslims, to express in their own unique ways their deepest spiritual aspirations" (p. 52). Even with episodes of strife (e.g., the Cordoban martyrdom movement of 851), tolerance was the rule and intolerance was the exception.

The final section provides a theological examination of the concept of dhimmī, beginning with the term's root, which means "blame," and implicates those who violate the rights of minorities with the censure of the political authorities and, in some cases, "divine censure" (p. 59). Shah-Kazemi gives an honest reading of how "dhimmitude" resulted in various problems for religious minorities, with the rejoinder that in comparison to Christendom's treatment of the same communities, life was marked by a sense of justice situated in Qur'anic texts such as Q. 10:47: "For every community (ummah) there is a messenger" (p. 61). Such divine commands gave Islamic rulers a moral imperative to treat Jews, Muslims, Hindus, Buddhists, and other non-Muslims as different but worthy. The author describes this as the norm that was "in accordance with the Qur'anic paradigm regarding the religious Other" (p. 61). In the case of jizyah, the tax placed upon non-Muslims, the intention was to legislate it "in a spirit of magnanimity and justice," absent condescension and humiliation (p. 65).

Part 2 examines the theological roots of what is seen within the monograph's first part, namely, the foundations of behavior witnessed in the Ottoman, Mughal, Fatimid, and Andalusian contexts. Shah-Kazemi describes this in the following way: "The Muslim record of tolerance is therefore to be regarded as an empirical, historically contingent expression of a spiritual ethos which comprises trans-historical, universally valid principles" (p. 76). The first half of this discussion focuses on the Qur'anic text and the moral imperative for Muslims to be tolerant toward their fellow human beings due to, but not limited to, the existence of different communities (ummah) (Q. 5:48), the importance of all of God's revelations (Q. 2:1-5), the existence of numerous messengers (Q. 2:285), and the Qur'an's status as a reminder (dhikrā) of previously forgotten messages (Q. 88:21 and Q. 87:9). The author then examines each value in detail - the confirmation and protection of all revelations preceding the Qur'an, the plurality of revelations as divinely willed, the diversity of human communities as intentional, and the differences resulting from these divine realities as finding resolution in the Hereafterand provides textual arguments for each one. The book's final part focuses 
on the Prophetic example, the "beautiful example" (uswah hasanah) established by Muhammad in his treatment of all creatures, from humans to animals (pp. 11-12).

Only at the monograph's end does the author ask: "Is this analysis not hopelessly naïve and excessively idealistic?” (p. 122). Some may say that this is the book's shortcoming, that it does not address those texts and historical incidences used to make the argument for an intolerant Islam. However, given that his focus is the tradition of tolerance in Islam, Shah-Kazemi has written a short but excellent study on that subject, one that provides ample material for those interested in Islam, Jewish-Christian-Muslim relations, and inter-religious dialogue.

Sophia Rose Shafi Visiting Assistant Professor of Islamic Studies (2011-2013) Iliff School of Theology, Denver, CO 